\title{
Çocuk Gözüyle Hemşirelik Bakım Kalitesinin Değerlendirilmesi
}

\section{Assessment of Nursing Care Quality from Child's Perspective}

\author{
Remziye Semerci ${ }^{1}$ (D) Melahat Akgün $\operatorname{Kostak}^{1}$ (D) İsmail Çetintaş ${ }^{1}$ (i) Esra Nur Kocaaslan ${ }^{1}$ (D) \\ ${ }^{1}$ Trakya Üniversitesi Sağık Bilimleri Fakültesi, Hemşirelik Bölümü, Çocuk Sağlığı ve Hastalıkları Hemşireliği Anabilim Dalı, Edirne, TÜRKiYE \\ Geliş tarihi/ Date of receipt: 08/09/2020 Kabul tarihi/ Date of acceptance: 14/02/2021 \\ (C) Ordu University Faculty of Health Sciences, Department of Nursing, Turkey, Published online: 18/04/2021
}

\section{ÖZ}

Amaç: Pediatri hemşirelerinin, çocuklara bireyselleştirilmiş bakım sunabilmesi için çocukların memnuniyetlerini ve hemşirelik bakımını çocuk gözünden değerlendirmesi gerekmektedir. Bu çalışmanın amacı çocuk gözü ile hemşirelik bakım kalitesini değerlendirmektir.

Yöntem: Tanımlayıcı nitelikteki çalışma, bir üniversite hastanesinde tedavi gören 7-13 yaşındaki 164 çocukla yürütüldü. Veriler 'Tanıtıcı Bilgi Formu' ve 'Çocukların Gözü ile Bakım Kalitesinin Değerlendirilmesi Ölçeği' ile toplandı. Veriler tanımlayıcı istatistikler, Mann-Whitney U testi, Kruskal Wallis H, post hoc Bonferroni testi ve Spearman korelasyon testleriyle analiz edildi.

Bulgular: Çocukların yaş ortalaması 10.86 $\pm 2.24, \% 59.1$ 'i erkek, \%40.2'si genel pediatri kliniklerinde tedavi almakta ve \%79.9'unun hastane deneyimi vard1. Çocukların \%33.5'inin kronik hastalığı vardı. Hastane deneyimi fazla olan, hematoloji/onkoloji kliniklerinde yatan çocukların toplam ölçek puanları ve 'Psikososyal bakım' alt boyut puan ortalamaları istatistiksel olarak daha yüksekti ( $\mathrm{p}<0.05)$. Kronik hastalığı olan çocukların toplam ölçek puan ve alt boyut puan ortalamaları istatistiksel olarak anlamlı düzeyde yüksekti $(\mathrm{p}<0.05)$. Çocukların hastaneye yatış sayısı ile toplam ölçek puanları, 'Psikososyal Bakım' ve 'Fiziksel bakım' alt boyut puanları arasında pozitif yönde ilişki bulundu $(\mathrm{p}<0.05)$. Çocukların hastane yatış süreleri ile 'Psikososyal Bakım' alt boyut puanları arasında pozitif yönde ilişki vardı $(\mathrm{p}=0.021)$.

Sonuç: Kronik hastalığı olan, hastane deneyimi olan, hastane yatış sayısı ve yatış süresi fazla olan çocuklar hemşirelik bakım kalitesini daha iyi olarak belirttiler. Bu sonuçlar doğrultusunda hemşirelerin yatıştan itibaren çocuklara klinik, hastalıkları ve tedavileri ile ilgili bilgilendirme yapmaları, fiziksel bakım dışında da çocukların hastanede eğlenceli vakit geçirmeleri için etkinlikler düzenlemeleri ve çocukların gereksinimlerini bütüncül değerlendirmeleri önerilebilir.

Anahtar kelimeler: Çocuk, hemşirelik, bakım kalitesi, hemşirelik bakımı

\section{ABSTRACT}

Objective: Pediatric nurses should evaluate children's satisfaction with nursing care from the children's perspective to provide individualized care. This study was aimed to evaluate the quality of nursing care from the children's perspective.

Methods: Descriptive study was carried out with 164 children aged 7-13 years in a university hospital. The data were collected by 'Information Form' and 'The Scale Evaluation Quality of Care From Children's Point of View'. Data were analyzed using descriptive statistics, Mann-Whitney U test, Kruskal Wallis H, post hoc Bonferroni test, and Spearman correlation.

Results: Children's age mean was $10.86 \pm 2.24,59.1 \%$ were male, $40.2 \%$ received treatment in the general pediatric service, and $79.9 \%$ had hospitalization experience. $33.5 \%$ of children had chronic diseases. The total scale scores and the "Psychosocial Care" subdimension mean scores of the children who were hospitalized in hematology/oncology clinics and who had more hospital experience were statistically higher $(\mathrm{p}<0.05)$. The total scale score and subscale mean scores of children with chronic disease were statistically significantly higher $(\mathrm{p}<0.05)$. A positive correlation was found between the number of hospitalizations of children and the mean score of total scale, 'Psychosocial Care' and 'Physical Care' subdimensions $(\mathrm{p}<0.05)$. It was a positive correlation between the length of hospitalization of children and the means score of the 'Psychosocial Care' subdimension $(\mathrm{p}=0.021)$.

Conclusion: Children with chronic illnesses, hospitalization experiences, more hospitalization, and a long stay in the hospital stated that nursing care was better. In line with these results, it can be suggested that nurses should inform the children about service, disease, and treatment from the hospitalization, organize activities for children in hospital, and spend time with children in addition to physical care to evaluate their needs holistically.

Keywords: Child, nursing, quality of care, nursing care

ORCID IDs of the authors: RS: 0000-0003-1999-9179, MAK: 0000-0003-0507-9638, IÇ: 0000-0002-9449-8801, ENK: 0000-0002-7890-7302 Sorumlu yazar/Corresponding author: Arş. Gör. Remziye Semerci

Trakya Üniversitesi Sağlık Bilimleri Fakültesi, Hemşirelik Bölümü, Çocuk Sağlığı ve Hastalıkları Hemşireliği Anabilim Dalı, Edirne, TÜRKIYE e-posta/e-mail: remziyesemerci@gmail.com

Bu araştırma 2. Uluslararası 7. Ulusal Pediatri Hemşireliği Kongresinde sözel bildiri olarak sunulmuştur (27-30 Kasım 2019).

Attf/Citation: Semerci R, Akgün Kostak M, Çetintaş İ, Kocaaslan EN. (2021). Çocuk gözüyle hemşirelik bakım kalitesinin değerlendirilmesi. Ordu Üniversitesi Hemşirelik Çalışmaları Dergisi, 4(1), 39-47. DOI: 10.38108/ouhcd.792360 


\section{Giriș}

Ebeveynler, çocuklarının doğumundan itibaren rutin takipleri veya hastalıkları nedeniyle sıklıkla hastanelere başvurmaktadırlar (Gündüz ve ark., 2016). Hastalık ve hastaneye yatma süreci çocuklar ve ebeveynleri için stres ve kaygı verici bir deneyimdir (Șener ve Karaca, 2017). Hastaneye yatış "Çocuğun hayatında önemli bir olay" olarak adlandırılmaktadır (Vessey 2003). Çocuklar için hastane ortamları kaos, bilinmezlik, ayrılık korkusu, terk edilme korkusu ve vücut bütünlüğünün zarar görmesi olarak algılanmaktadır (Açıkgöz ve ark., 2019; Gündüz ve ark., 2016; Wilson ve ark., 2010;).

Literatürde çocuklarda hastaneye yatmaya bağlı olarak anksiyete, korku, stres, regresyon, mutsuzluk, apati, hiperaktivite, agresyon ve uyku düzensizlikleri gibi davranış ve tepkilerin görülebileceği bildirilmektedir (Açıkgöz ve ark., 2019; Başbakkal ve ark., 2010; Melnyk 2000; Öztürk ve Topan, 2018). Cocukların hastane ve hastalık durumuna verdiği tepkiler farklılık göstermektedir (Gönener 2009). Bu tepkiler çocuğun yaş, hastalığın akut ya da kronik olması, önceki hastane deneyimleri ve yatış sürecinde çocuğun sağlık profesyonelleri tarafindan desteklenmesi gibi faktörlerden etkilenmektedir (Gündüz ve ark., 2016; Taşdemir Akkavak ve Sarıkaya Karabudak, 2019; Wilson ve ark., 2010). Devam eden korku ve kayg1 çocuğun sağlık bakımına katılımını engelleyebilir hatta çocuğun tedavi sürecini olumsuz etkileyebilir (Gündüz ve ark., 2016). Çocukların verdiği tepkiler giderilmediği sürece bu tepkiler çocuklar için örseleyici olabilmekte ve yaşam kalitesini düşürebilmektedir (Başbakkal ve ark., 2010).

Çocuğun hastalık ve hastaneye yönelik verdiği tepkileri gidermek amaciyla hastanelerde çocuğun gelişimini ve konforunu destekleyen bir ortamın oluşturulması önemlidir (Comparcini ve ark., 2018; Çakirer Çalbayram ve ark., 2018). Çocuğun bilişsel, fizyolojik, psikolojik ve sosyal özellikleri göz önünde bulundurularak bütüncül bakım verilmesi gerekmektedir (Başbakkal ve ark., 2010). Bu kapsamda, sağlık profesyonellerine özellikle çocuğun primer hemşiresine önemli sorumluluklar düşmektedir (Noreña Peña ve Cibanal Juan, 2011). $\mathrm{Bu}$ kritik durumda, pediatri hemşirelerinin bakımının önemli bir kısmını oluşturan terapötik iletişim ve oyunu hastanede yatan çocukların stresle baş etmelerini kolaylaştırmak amacıyla kullanmaları büyük önem taşımaktadır (Avan 2020; Yayan ve Zengin, 2018). Çocuğun gelişim özelliklerine uygun olarak kullanılan terapötik iletişim ve oyun, çocuğun hastaneye yatma nedenini anlayabilmesine ve bu bilinmezliğe karşı etkili baş etme yöntemlerini geliştirmelerine olanak sağlamaktadır (Yati ve ark., 2017; Yayan ve Zengin, 2018). Literatürde, çocuklarda hastaneye yatmaya bağlı oluşan anksiyeteyi azaltmak amaciyla kullanılan terapötik iletişim ve oyununun çocukların anksiyete düzeylerini azaltmada etkili olduğu ve çocukların tedaviye ve hastalığa olan uyumlarını arttırdığg belirtmektedir (Kapkin ve ark., 2020; Silva ve ark., 2017; Yati ve ark., 2017). Bu bilgiler 1şığında, pediatri hemşiresinin terapötik iletişim ve oyunu kullanarak çocuk için destekleyici bir ortam (hastal1k-tedavi konusunda bilgilendirme, klinikodasını tanıtma, çocuğun eğlence aktivitelerini planlanma, klinikte yatan diğer çocuklar ile tanıştırma vb.) oluşturma kritik bir önem taşımaktadır (Comparcini ve ark., 2018).

Çocuk için destekleyici ortamın oluşturulması çocuğun bakım memnuniyetinin ve yaşam kalitesinin artmasını sağlayacaktır (Ryan-Wenger ve Gardner, 2012; Yagil ve ark., 2010). Literatürde genellikle çocukların hastane ve hastalığa karşı verdiği tepkiler ya da hastane, hastalık, sağlık profesyonellerine olan algilarını inceleyen çalışmalar yapılmıştır (Gündüz ve ark., 2016; Öztürk ve Topan, 2018; Taşdemir Akkavak ve Sarıkaya Karabudak, 2019). Çocukların hemșirelik bakımına yönelik düşüncelerini değerlendiren çalışmalar konusunda literatürde sınırlılık söz konusudur (Comparcini ve ark., 2018). Çocukların perspektifinden hemşirelik bakım kalitesinin değerlendirilmesi; çocukların bakım ihtiyaçlarının belirlenmesine, beklentilerinin karşılanmasına ve hemşirelik girişimlerinin planlamasına katk1 sağlayacaktır (Harder ve ark., 2018; Yagil ve ark., 2010).

Bakım memnuniyeti, bireyselleştirilmiş bakımın en önemli göstergelerinden biridir. Çocukların bakım memnuniyeti ve yaşam kalitelerini arttırmak amacıyla pediatri kliniklerinde hemşirelik bakım kalitesinin çocuklar tarafından değerlendirilmesi gerekmektedir. Bu değerlendirme çocukların bakım gereksinimlerinin belirlenmesini de sağlayacaktır. Hemşirelik bakım kalitesinin değerlendirilmesi ayrıca bakım memnuniyetinin de somut bir ölçüsü olacaktır. Bu bilgiler 1şı̆̆ında bu çalışmanın amacı, 7-13 yaş grubundaki çocukların perspektifinden hemşirelik bakım kalitesinin değerlendirilmesidir.

\section{Araştırma Soruları}

1. Çocuk gözüyle hemşirelik bakım kalitesi ne düzeydedir? 
2. Çocuk gözüyle hemşirelik bakım kalitesini etkileyen faktörler nelerdir?

\section{Yöntem}

\section{Araștırmanın Tipi}

Çalışma tanımlayıcı nitelikte bir araştırmadır.

\section{Araștırmanın Yeri ve Zamanı}

$\mathrm{Bu}$ çalışma 15 Mayıs-27 Ağustos 2019 tarihlerinde Trakya Üniversitesi Sağlik Araştırma ve Uygulama Merkezinde yapıldı. Araştırma, çocuk onkoloji/hematoloji kliniği, çocuk hastalıkları kliniği ve çocuk cerrahi kliniğinde yürütüldü. Hastane Trakya Bölgesinin en büyük üniversite hastanesidir ve 68 yataklı pediatri kliniğine sahiptir.

\section{Araștırmanın Örneklemi}

Araştırmanın örneklemini, Trakya Üniversitesi Sağlık Araștırma ve Uygulama Merkezinde pediatri kliniklerinde tedavi gören 7-13 yaş aralığındaki 164 çocuk oluşturdu. Araștırmada amaca uygun örnekleme yöntemi kullanıldı ve örneklem sayısı GPower 3.1.9.4. versiyon programı kullanılarak hesaplandı ve 0.80 güç, $0.05 \mathrm{p}$ değeri ile yapılan hesaplamada gerekli örneklem sayıs1 164 olarak bulundu.

\section{Araştırmaya Alınma ve Dışlanma Kriterleri}

Araştırmaya, çocuk kliniklerinde en az 2 gün yatarak tedavi olan, ana dili Türkçe olan, 7-13 yaş aralığında olan, görsel, işitsel ve zihinsel bir problemi olmayan, çalışma için ebeveynleri onay veren gönüllü çocuklar dahil edildi.

\section{Araștırmanın Değișkenleri}

Araştırmanın bağımsız değişkenleri; çocukların ve ebeveynlerin sosyo-demografik özellikleri (yaş, cinsiyet, anne-baba çalışma durumu, anne-baba eğitim durumu, çocuğun hastane deneyimi, kronik bir hastalığa sahip olma durumu vb.), bağımlı değişkenler ise; 'Çocukların Gözü ile Bakım Kalitesinin Değerlendirilmesi Ölçeği' toplam puan ortalaması ve alt boyutlarının puan ortalamalarıdır.

\section{Veri Toplama Araçları}

Araștırma verileri 'Tanıtıcı Bilgi Formu' ve 'Çocukların Gözü ile Bakım Kalitesinin Değerlendirilmesi Ölçeği’ aracılığıyla toplandı.

Tanıtıcı Bilgi Formu: Form, araştırmacılar tarafından literatür taraması sonucunda olușturuldu (Taşdemir Akkavak ve Karabudak, 2019; Yagil ve ark., 2010; Wilson ve ark., 2010). Form, çocuğa ait tanımlayıcı özellikleri ile ilgili 10 soru (yaş, cinsiyet, hastanede kalış süresi, hastaneye yatış süresi, kronik bir hastalığa sahip olma durumu vb.); ebeveynlere ait tanımlayıcı özellikleri ile ilgili 7 soru (yaş, anne-baba eğitim düzeyi, anne-baba çalıșma durumu vb.) olmak üzere toplam 17 sorudan oluşmaktadır.

Cocukların Gözü ile Bakım Kalitesinin Değerlendirmesi Ölçeği: Ölçek Yılmaz tarafından 2018 yılında geliștirilmiștir (Yılmaz 2018). Ölçekte 15 madde bulunmaktadır. Her madde beșli likert tipte (1=Hiçbir zaman katılmıyorum, 5=Her zaman katılıyorum) öz bildirime dayalı olarak puanlandırıldı. Ölçekte olumsuz madde bulunmamaktadır. Ölçek üç alt boyuttan oluşmaktadır bunlar; psikososyal bakım (6 madde; $3,5,7,8,14,15$. maddeler), fiziksel bakım (5 madde; $4,10,11,12,13$. maddeler) ve bilgilendirme (4 madde; 1, 2, 6, 9. maddeler) alt boyutlarıdır. Ölçekten alınabilecek minimum puan 15 , maksimum puan 75 'tir. Alt boyutlardan alınan puanlar artıkça o bakıma yönelik bakım kalitesinin arttığını göstermektedir. Ölçeğin toplam Cronbach's alfa katsayısı 0.86 'dır. Bu çalışma için ölçeğin Cronbach's alfa katsayıs1 0.98 olarak bulundu.

\section{Veri Toplama Süreci}

Veri toplama süresince, araştırmacılar her gün pediatri klinik sorumluları ile görüşerek çocukların örnekleme dahil edilme kriterleri kapsamında değerlendirildi. Örneklem seçim kriterlerine uygun olan çocuklar ilk olarak araştırmacılar ile tanışarak güvenli bir ilişki kurulduktan sonra çocuk ve ebeveyn araştırma hakkında bilgilendirildi. Çalıșmaya katılmaya gönüllü olan çocukların ebeveynlerinden yazılı izin, çocuklardan ise sözel onam alındı. Veriler çocuğun kendisini rahat hissedebilmesi için kendi hasta odasında ve yatağında, yüz yüze görüşme yöntemi ile çocuğun öz bildirimine dayalı olarak topland1. Veri toplama süreci yaklaşık 10-15 dakika sürdü.

\section{Verilerin Değerlendirilmesi}

Veriler, lisanslı IBM SPSS 23 paket programı (IBM SPSS Statistics for Windows, Version 23.0. Armonk, NY: IBM Corp.) kullanılarak analiz edildi. Ebeveynlerin ve çocukların tanımlayıcı özelliklerinin değerlendirilmesinde sayı, yüzde dağılımları, ortalama ve standart sapma kullanıldı. Normal dağılım, Shapiro-Wilk-W testi ile değerlendirildi. Ölçek puan ortalamalarının varyans homojenliği sonuçlarına göre non-parametrik testler kullanıldı. Tanımlayıcı özelliklerle ölçek skorları arasındaki ilişkilerin incelenmesinde Mann Whitney $\mathrm{U}$ testi, Kruskal-Wallis $\mathrm{H}$ testi, Bonferroni düzeltmeli Mann Whitney $U$ testi ve spearman korelasyon analizi kullanıldı. Spearman korelasyon analizinde; $0.00-0.25=$ çok zayıf, $0.26-0.49=$ zayıf, $0.50-0.69=$ orta, $0.70-0.89=$ yüksek, $0.90-1.00=$ çok yüksek ilişki korelasyon katsayıları esas alındı. 
Sonuçlar \%95'lik güven aralığında ve anlamlılık $\mathrm{p}<0.05$ düzeyinde değerlendirildi.

\section{Bulgular}

Çalışmaya dahil edilen çocukların yaş ortalaması $10.86 \pm 2.24$ ve \%59.1'i erkek idi. Çocukların $\% 76.2$ 'si çekirdek aile yapısında ve \%80.5'inin aile gelir düzeyi "gelir gidere denk" idi. Annelerin \%79.9'u, babaların ise \%11.6'sı çalışmıyordu. Annelerin \%49.4'ü ilkokul mezunu, babaların \%38.3'ü lise mezunuydu (Tablo 1).

Tablo 1. Çocukların tanımlayıcı özellikleri ( $\mathrm{n}=164)$

\begin{tabular}{|c|c|c|}
\hline Değişkenler & \multicolumn{2}{|c|}{ Ort \pm SS } \\
\hline Çocuk Yaş & \multicolumn{2}{|c|}{$10.86 \pm 2.25$} \\
\hline Cinsiyet & $\mathbf{n}$ & $\%$ \\
\hline $\mathrm{K}_{1 \mathrm{Z}}$ & 67 & 40.9 \\
\hline Erkek & 97 & 59.1 \\
\hline \multicolumn{3}{|l|}{ Aile yapısı } \\
\hline Çekirdek & 125 & 76.2 \\
\hline Geniş & 39 & 23.8 \\
\hline \multicolumn{3}{|l|}{ Aile Geliri } \\
\hline Gelir giderden az & 12 & 7.3 \\
\hline Gelir gidere denk & 132 & 80.5 \\
\hline Gelir giderden çok & 20 & 12.2 \\
\hline \multicolumn{3}{|l|}{ Anne çalışma durumu } \\
\hline Çalışıyor & 33 & 20.1 \\
\hline Çalışmıyor & 131 & 79.9 \\
\hline \multicolumn{3}{|l|}{ Annenin eğitim düzeyi } \\
\hline Okuma yazma bilmiyor & 9 & 5.5 \\
\hline İlkokul & 81 & 49.4 \\
\hline Ortaokul & 31 & 18.9 \\
\hline Lise & 38 & 23.2 \\
\hline Üniversite ve üstü & 5 & 3.0 \\
\hline \multicolumn{3}{|l|}{ Baba çalıșma durumu } \\
\hline Çalışıyor & 145 & 88.4 \\
\hline Çalışmıyor & 19 & 11.6 \\
\hline \multicolumn{3}{|l|}{ Babanın eğitim düzeyi } \\
\hline Okumaya yazma bilmiyor & 13 & 7.9 \\
\hline İlkokul & 55 & 33.5 \\
\hline Ortaokul & 17 & 10.4 \\
\hline Lise & 62 & 38.3 \\
\hline Üniversite ve üstü & 17 & 9.9 \\
\hline
\end{tabular}

Çocukların hastalık/hastaneye yatma ile ilişkili tanımlayıcı özelliklerine Tablo 2'de yer verilmiştir. Cocukların \%40.2'si "Çocuk Hastalıkları Servisinde", \%35.4'ü "Cocuk Cerrahi Servinde" ve \%24.4'ü "Çocuk Hematoloji/Onkoloji Servisinde" tedavi almaktaydı. Çocukların \%33.5'inin kronik bir hastalığ1 vardı ve \%79.9'u daha önce hastaneye yatmıştı. Çocukların hastane yatış süreleri ortalama $6.17 \pm 8.89$ (Min: 2 Max: 58), hastane yatış sayısı ise ortalama $4.53 \pm 4.00$ (Min:1-Max:20) idi.
Tablo 2. Çocukların hastalık/hastaneye yatma ile ilgili tanımlayıcı özellikler ( $\mathrm{n}=164)$

\begin{tabular}{|c|c|c|}
\hline Değişkenler & \multicolumn{2}{|c|}{ Ort \pm SS } \\
\hline Hastane yatış süresi (gün) & \multicolumn{2}{|c|}{$\begin{array}{c}6.17 \pm 8.89 \\
\text { (Min: } 2 \text { Max: } 58 \text { ) }\end{array}$} \\
\hline Hastaneye yatış sayısı & \multicolumn{2}{|c|}{$\begin{array}{c}4.53 \pm 4.00 \\
\text { (Min: } 1 \text { Max: } 20 \text { ) }\end{array}$} \\
\hline Yattığı Servis & $\mathbf{n}$ & $\%$ \\
\hline $\begin{array}{l}\text { Çocuk } \\
\text { Hematoloji/Onkoloji }\end{array}$ & 40 & 24.4 \\
\hline Çocuk Cerrahi & 58 & 35.4 \\
\hline Çocuk Hastalıkları & 66 & 40.2 \\
\hline \multicolumn{3}{|l|}{ Kronik hastalık durumu } \\
\hline Var & 55 & 33.5 \\
\hline Yok & 109 & 66.5 \\
\hline \multicolumn{3}{|l|}{ Hastane deneyimi } \\
\hline Var & 131 & 79.9 \\
\hline Yok & 33 & 20.1 \\
\hline
\end{tabular}

Ort: Ortalama, SS: Standart Sapma, Min: Minimum, Max: Maximum

Çocukların 'Çocuk Gözü ile Bakım Kalitesinin Değerlendirilmesi Ölçeği’ toplam puan ortalaması $47.81 \pm 16.96$, 'Psikososyal Bakım' alt boyut 14.21 \pm 8.03 ; 'Fiziksel Bakım' alt boyut $19.95 \pm 6.16$ ve 'Bilgilendirme' alt boyut puan ortalamas1 $13.64 \pm$ 5.10'dur. (Tablo 3).

Tablo 3. Cocukların 'Cocuk Gözü ile Bakım Kalitesinin Değerlendirilmesi Ölçeği' toplam puan ortalaması ile alt boyut puan ortalamaları

\begin{tabular}{lcc}
\hline $\begin{array}{l}\text { Ölçek ve Alt } \\
\text { Boyutlar }\end{array}$ & Ort \pm SS & Min - Max \\
\hline Psikososyal & $14.21 \pm 8.03$ & $6.00-30.00$ \\
Bakım & $19.95 \pm 6.16$ & $5.00-25.00$ \\
Fiziksel Bakım & $13.64 \pm 5.10$ & $4.00-20.00$ \\
Bilgilendirme & $47.81 \pm 16.96$ & $15.00-75.00$ \\
\hline TOPLAM &
\end{tabular}

Ort: Ortalama, SS: Standart Sapma, Min: Minimum, Max: Maximum

Cocukların hastalık/hastaneye yatma ile ilgili özelliklerine göre "Çocukların Gözü ile Bakım Kalitesinin Değerlendirilmesi Ölçeğinin" toplam ve alt boyut puan ortalamalarının dağılımına Tablo 4' de yer verilmektedir. Çocukların yattığı servis ile ölçek toplam ve alt boyut puan ortalamaları arasında istatistiksel olarak anlamlı fark vardır $(\mathrm{p}<0.05)$ Çocuk hematoloji/onkoloji servisindeki çocukların bildirdikleri ölçek toplam puan ortalaması, 'Psikososyal Bakım' ve 'Fiziksel Bakım' alt boyut 
puan ortalamaları diğer servisteki çocukların bildirdiklerinden daha yüksek idi.

Çocukların kronik hastalık durumu ile ölçek toplam ve alt boyut puan ortalamaları arasında istatistiksel olarak anlamlı fark bulunmuştur $(\mathrm{p}<0.05)$. Kronik hastalığı olan çocukların bildirdikleri ölçek toplam ve alt boyut puan ortalaması kronik hastalığı olmayan çocukların bildirdiklerinden daha yüksek idi (Tablo 4).
Çocukların hastane deneyimine sahip olma durumları ile ölçek toplam ve alt boyut puan ortalamaları arasında istatistiksel olarak anlamlı fark saptanmıştır $(p<0.05)$. Hastane deneyimi olan çocukların bildirdikleri ölçek toplam ve 'Psikososyal Bakım' alt boyut puan ortalaması hastane deneyimi olmayan çocukların bildirdiklerinden daha yüksek idi (Tablo 4).

Tablo 4. Çocukların hastalık/hastaneye yatma ile ilgili özelliklerine göre ölçek puan ortalamalarının dağılımı $(\mathrm{n}=164)$

\begin{tabular}{|c|c|c|c|c|}
\hline Değişken & $\begin{array}{c}\text { Ölçek } \\
\text { Toplam }\end{array}$ & $\begin{array}{c}\text { Psikososyal Bakım } \\
\text { Alt Boyutu }\end{array}$ & $\begin{array}{c}\text { Fiziksel Bakım Alt } \\
\text { Boyutu }\end{array}$ & $\begin{array}{l}\text { Bilgilendirme } \\
\text { Alt boyutu }\end{array}$ \\
\hline & Median (Q1-Q3) & Median (Q1-Q3) & Median (Q1-Q3) & Median (Q1-Q3) \\
\hline \multicolumn{5}{|l|}{ Yattığı Servis } \\
\hline $\begin{array}{l}\text { Çocuk } \\
\text { Hematoloji/Onkoloji }{ }^{\mathrm{a}}\end{array}$ & $56.00(45.00-63.00)$ & $16.50(13.00-24.00)$ & $23.00(19.00-25.00)$ & $15.50(13.00-17.00)$ \\
\hline Çocuk Cerrahi ${ }^{\mathrm{b}}$ & $45.00(37.00-59.00)$ & $10.00(6.00-15.00)$ & $21.50(20.00-25.00)$ & $14.00(10.00-19.00)$ \\
\hline Çocuk Hastalıkları $^{\mathrm{c}}$ & $45.00(31.00-60.00)$ & $12.00(6.00-18.00)$ & 20.50(17.00-25.00) & $14.00(8.00-18.00)$ \\
\hline MWU*, p & $\begin{array}{c}a-b=823.50, \mathbf{p}=\mathbf{. 0 1 5} \\
a-c=913.50, \mathbf{p}=\mathbf{. 0 0 8} \\
b-c=1884.50, p=.882\end{array}$ & $\begin{aligned} a-b & =628.50, \mathbf{p}<.001 \\
a-c & =880.50, \mathbf{p}=\mathbf{. 0 0 4} \\
b-c & =1767.00, p=.450\end{aligned}$ & $\begin{array}{c}a-b=1068.50, \mathbf{p}=\mathbf{. 4 9 6} \\
a-c=989.50, \mathbf{p}=\mathbf{. 0 2 8} \\
b-c=1635.50, p=.156\end{array}$ & $\begin{array}{l}\mathrm{a}-\mathrm{b}=1052.50, \mathrm{p}=.434 \\
\mathrm{a}-\mathrm{c}=1023.00, \mathrm{p}=.052 \\
\mathrm{~b}-\mathrm{c}=1778.50, \mathrm{p}=.495\end{array}$ \\
\hline \multicolumn{5}{|c|}{ Kronik hastalığa sahip olma } \\
\hline Evet & $58.00(46.00-69.00)$ & $15.00(13.00-26.00)$ & $23.00(19.00-25.00)$ & $16.00(13.00-19.00)$ \\
\hline Hayır & $45.00(35.00-54.00)$ & $10.00(6.00-16.00)$ & $21.00(15.00-25.00)$ & $13.00(10.00-19.00)$ \\
\hline $\mathbf{M W U}^{* *}, \mathbf{p}$ & $\begin{array}{c}1624.50 \\
<.001 \\
\end{array}$ & $\begin{array}{c}2271.00 \\
\mathbf{. 0 1 0} \\
\end{array}$ & $\begin{array}{c}2197.00 \\
.005 \\
\end{array}$ & $\begin{array}{c}1804.00 \\
<. \mathbf{0 0 1} \\
\end{array}$ \\
\hline \multicolumn{5}{|c|}{ Hastane deneyimine sahip olma } \\
\hline Evet & $49.00(41.00-64.00)$ & $13.00(6.00-22.00)$ & $23.00(17.00-25.00)$ & $14.00(11.00-18.00)$ \\
\hline Hayır & $43.00(35.00-51.00)$ & $10.00(6.50-14.00)$ & $21.00(17.00-24.50)$ & $12.00(8.00-18.00)$ \\
\hline $\mathbf{M W U}^{* *}, \mathbf{p}$ & $\begin{array}{c}1626.50 \\
\mathbf{. 0 2 8} \\
\end{array}$ & $\begin{array}{c}1672.50 \\
\mathbf{. 0 4 2} \\
\end{array}$ & $\begin{array}{c}1812.00 \\
.144 \\
\end{array}$ & $\begin{array}{c}1921.50 \\
.323 \\
\end{array}$ \\
\hline
\end{tabular}

MWU*: Bonferroni düzeltmeli Mann Whitney Testi; MWU**: Mann Whitney U testi, Q1-Q3: Çeyrekler arası aralık (İnterquartile range - IQR)

Çocukların hastane yatış süreleri ve hastaneye yatış sayıları ile ölçek toplam ve alt boyut puan ortalamaları arasındaki ilişkiye Tablo 5 ' de yer verilmiştir. Çocukların hastaneye yatış süreleri ile 'Psikososyal Bakım' alt boyut puan ortalamaları arasında pozitif yönde çok zayıf ilişki olduğu belirlendi ( $\mathrm{r}=0.180 \mathrm{p}=0.021)$. Çocukların hastaneye yatış sayısı ile ölçek toplam puan ortalamaları arasında pozitif yönde zayıf ilişki olduğu ( $\mathrm{r}=0.251$; $\mathrm{p}<0.001)$ belirlendi. Çocukların hastaneye yatış sayıs1 ile 'Psikososyal Bakım' alt boyut puan ortalamaları arasında pozitif yönde zayıf ilişki olduğu $(r=0.286 ; p<0.001)$; 'Fiziksel Bakım' alt boyut puan ortalamaları arasında ise pozitif yönde çok zayıf ilişki olduğu $(r=0.200 ; p=0.009)$ saptandı.

Tablo 5. Çocukların bazı özellikleri ile ölçek puan ortalamaları arasındaki korelasyon katsayıları ve anlamlılık düzeyi $(\mathrm{n}=164)$

\begin{tabular}{cccccc}
\hline Değişkenler & $\begin{array}{c}\text { Ölçek } \\
\text { Toplam }\end{array}$ & $\begin{array}{c}\text { Psikososyal Bakım } \\
\text { Alt Boyutu }\end{array}$ & $\begin{array}{c}\text { Fiziksel Bakım Alt } \\
\text { Boyutu }\end{array}$ & $\begin{array}{c}\text { Bilgilendirme } \\
\text { Alt boyutu }\end{array}$ \\
\hline $\begin{array}{c}\text { Hastane yatış süresi } \\
\text { (gün) }\end{array}$ & $\mathrm{r}_{\mathrm{s}}$ & .139 & .180 & .005 & .116 \\
\hline p & .075 & $\mathbf{. 0 2 1}$ & .945 & .140 \\
\hline $\begin{array}{c}\text { Hastaneye yatış } \\
\text { sayısı }\end{array}$ & $\mathrm{r}_{\mathrm{s}}$ & .251 & .286 & .200 & .142 \\
& $\mathrm{p}$ & $<.001$ & $\mathbf{< . 0 0 1}$ & $\mathbf{. 0 0 9}$ & .100 \\
\hline
\end{tabular}

$\mathrm{r}_{\mathrm{s}}=$ Sperman Korelasyon Analizi

Tartışma 
Çocuklar hastaneye yattıkları andan itibaren bir bilinmezlik ve kaos yaşamaktadırlar. Çocukları bu bilinmezlikten kurtarmak için hastaneye yatıştan itibaren, hemşireler tarafindan bakıma/tedaviye dahil edilmeleri, süreç hakkında bilgilendirilmeleri ve destekleyici ortamın oluşturulması gerekmektedir (Burns-Nader 2017; Comparcini ve ark., 2018). Pediatri hemşirelerinin, çocuğu desteklemesi ve çocuğun bakıma yönelik memnuniyetlerini arttırmaları önemlidir (Taşdemir Akkavak ve Karabudak, 2019). Bu kapsamda, çocuğun hemşirelik bakım kalitesinden memnun kalma durumunun sorgulanması önemlilik arz etmektedir. Çocuğun öz bildirimine dayalı çalışmaların somut bir veri oluşturacağ düşüncesiyle bu çalışmada çocuk perspektifinden hemşirelik bakım kalitesinin değerlendirilmesi amaçlanmıştır. Araştırma sonucunda, çocukların tedavi aldığı servis, kronik hastalığa sahip olma durumları, hastane deneyimleri, hastane yatış sayıları gibi özelliklerinin hemşirelik bakım kalitesine yönelik değerlendirmelerini etkilediği belirlendi.

$\mathrm{Bu}$ araştırmada, çocuk hematoloji/onkoloji servisinde yatan çocukların bildirdiği genel hemşirelik bakım kalitesi, psikososyal ve fiziksel bakım kalitesi diğer çocuklardan daha yüksek idi. Çalışma bulgularımız literatürdeki sonuçlara benzerlik göstermekte idi. Literatürde, çocukların hemşirelik algısını ve hemşirelik bakımına yönelik tutumlarını yatış yapılan klinik türünün etkili olduğu bildirilmektedir (Comparcini ve ark., 2018; İnal Emiroğlu ve Akay, 2008). Çocuk hematoloji/onkoloji servisinde yatan çocukların kronik hastalığa sahip oldukları düşünülürse, akut hastalığı olan çocuklardan daha fazla hastane yatış yaptıkları söylenebilir. S1klıkla hastaneye yatırılan bu çocuklar hastane ortamına, tedavi ve bakım prosedürlerine, sağlık profesyonellerine aşinadır. $\mathrm{Bu}$ aşinalık, çocukların hastaneden neler beklediğini ve alacakları bakım konusunda fikir sahibi olmalarını sağlamaktadır. (Bolat 2018). Bu durumun çocuğun bakım memnuniyetini de etkileyebildiği düşünülebilir. Hastaneye yatma çocuklar için anksiyeteye neden olan bir durumdur. Yapilan çalışmalarda/literatürde kronik hastalıkları olan çocukların akut hastalıkları olan çocuklara göre anksiyete düzeylerinin daha düşük olduğu bulunmuştur (Gerçeker ve ark., 2018; Şen Beytut ve ark., 2019). Kronik hastalığı olan çocukların hastane deneyimine sahip olmaları nedeni ile anksiyetenin düzeylerinin düşük olduğu, aynı şekilde tekrarlı yatışlarda çocuk ve hemşire arasındaki ilişkinin gelişmesi ile hemşirelerin çocukların beklentilerini karşıladığı, bu durumun çocuğun hemşirelik bakımına yönelik memnuniyetini arttırdığ 1 söylenebilir.

Çocukların hastaneye yatış deneyimlerine ilişkin görüş ve algıları sağlık hizmetlerinin etkinliğinin kalitesinin izlenmesinde ve değerlendirilmesinde önemli bir rol oynamaktadır (Comparcini ve ark., 2018; Temel ve ark., 2018). Bu araştırmada, hastane deneyiminin çocukların hemşirelik bakım kalitesine yönelik değerlendirmelerini etkilediği, hastaneye yatış deneyimi olan çocukların genel hemşirelik bakımını ve psikososyal bakım kalitesini daha yüksek değerlendirdikleri belirlendi. Pelander ve arkadaşları (2007) Finlandiya'da çocuklar ile yürüttükleri araştırmada, hastane deneyimi olan çocukların hemşirelik bakım kalitesini daha iyi değerlendikleri belirtilmiştir (Pelander ve ark., 2007). Literatürde, hemşire ve çocuk arasındaki iletişim ve etkileșimin çocuğun servise kabulü ile başladığ 1 belirtilmektedir (Taşdemir Akkavak ve Sarıkaya Karabudak, 2019). Çocuk ve hemşire arasındaki bu ilişki çocuğun tedavi ve hastalığa olan uyumunu kolaylaştırırken, hemşireye güven duymasını da sağlamaktadır (İnal ve Akgün, 2003). $\mathrm{Bu}$ bilgiler 1şı̆̆ında çocukların hastane yatış deneyiminin olması, çocuk ve hemşire arasındaki ilişkinin gelişmesi ile hemşirelerin çocukların beklentilerini karşıladığ ${ }_{1}$, bu durumun çocuğun hemşirelik bakımına yönelik memnuniyetini arttırdığı söylenebilir.

Çocuklarda hastaneye yatışa bağlı oluşan anksiyete ve stresi azaltmanın en etkili çözümlerinden biri de yatıştan itibaren çocuğun bilgilendirilmesi ve bakımına dahil edilmesidir. $\mathrm{Bu}$ araştırmada, kronik hastalığa sahip olan çocuklar hemşirelerin bilgilendirmeye yönelik bakım kalitelerini daha iyi değerlendirirken, kronik hastalığa sahip olmayan çocuklar daha düşük olarak belirtiler. Teksoz ve arkadaşları (2017) tarafından yapılan deneysel çalışmada, hemşireler tarafindan yaratıcı oyunlar ile çocuklara tedavi ve hastalık süreci hakkında bilgi verilen ve bakıma dahil edilen çocukların hemşirelik bakım memnuniyetinin daha yüksek olduğu belirlenmiştir (Teksoz ve ark., 2017). Boztepe ve arkadaşları (2017), hastane ve tedavi süreci ile ilgili bilgilendirilmeyen çocukların kaygı düzeylerinin fazla olduğu bildirilmiştir (Boztepe ve ark., 2017). Bu bilgiler 1şığında, süreç hakkında bilgilendirilen çocuklarda hastane/hastalığa yönelik bilinmezlik, stres, kaygı ve korku duygularının azaldığ1 ve hemşirelik bakım memnuniyetlerinin arttığı söylenebilir. Olumsuz duyguları azalan çocuk 
bakımına aktif olarak katılabilir, kendi duygu, düşünce ve gereksinimlerini kolaylıkla bildirebilir. $\mathrm{Bu}$ kapsamda çocuğun hastaneye yatıştan itibaren hemşireler tarafindan desteklenmesi ve süreç hakkında bilgilendirilmesi önemlidir.

$\mathrm{Bu}$ çalışmada, çocukların hastaneye yatış sayısı arttıkça hemşirelik bakım kalitesini, psikososyal bakımı ve fiziksel bakımı daha iyi değerlendirdikleri belirlendi. Çalışma sonucunda, ilk kez hastaneye yatan çocukların hemşirelik bakım kalitesini düşük değerlendirdikleri, hastane yatış sayısı ve hastanede kalma süresinin artması ile çocukların bildirdikleri hemşirelik bakım kalitesinin de arttığ görülmektedir. Çocukların hastane ortamına uyumları gelişimsel özelliklerinden dolayı zordur. $\mathrm{Bu}$ nedenle pediatri hemşireleri, çocukların yetişkinlerden farklı ihtiyaçları olduğunu bilmelidir. Kişilerarası ilişkiler ve hastalarla etkili iletişim hemşirelik bakım kalitesinin önemli bir belirleyicisidir. Hemşireler çocuklar ile iletişimi başlatmak ve çocukların kendilerini ifade edebilmelerini sağlamak amacıyla kliniklerde etkinlikler düzenlemelidir (Noreña Peña ve Cibanal Juan, 2011). Bu kapsamda hemşirelerin çocukların psikososyal bakım ihtiyaçlarını karşılamak amacıyla eğlence faaliyetlerini planlaması, çocuklara zaman ayırarak sohbet etmeleri, çocukları serviste yatan diğer çocuklar ile tanıştırmaları vb. etkinlikleri yapmas1 gerekmektedir. Hemşirelerin fiziksel bakım ihtiyaçlarını karşılamak amacıyla çocukların ağrılarını yönetmeleri, yaptıkları ilaç hakkında bilgi vermeleri, ilaç uygulamaları sırasında çocuk ile iletişime geçmeleri; bilgilendirme ile ilgili bakım ihtiyaçlarını karşılamak için tedavi ve hastalık hakkında, yattığı servis ve odası hakkında bilgi vermesi gerekmektedir (Y1lmaz 2018). Literatürde, okul çağı çocuklarıyla yapılmış olan birçok kalitatif çalışmada, çocukların hemşirelerden beklentileri ve çocukların hemşirelere yönelik algıları çizim yöntemleriyle değerlendirilmiş ve çocukların hemşirelerden süreç hakkında bilgilendirme, oyun etkinlikleri, bakıma dahil edilme, güler yüz ve iletişim kurma gibi beklentilerinin olduğu belirlenmiştir (Loureiro ve ark., 2019; Pelander ve Leino-Kilpi, 2004). Bu sonuçlar kapsamında pediatri hemşirelerinin tedavi ve bakım odaklı girişimlerde bulunduğu, çocukların psikososyal ihtiyaçlarını geri planda bıraktıkları söylenebilir.

\section{Sonuç ve Öneriler}

Kronik bir hastalığı olan, daha önce hastane deneyimi olan ve hematoloji/onkoloji kliniklerinde tedavi gören çocukların hemşirelik bakım kalitesini daha iyi bildirdikleri belirlendi. Çocukların hastane yatış sayısı ve hastanede kalış süreleri arttıkça hemşirelik bakım kalitesi için bildirdikleri puanların arttığı görüldü. Çocuklar tarafından yapılan değerlendirmede, hemşirelerin, 'Çocukların Gözü ile Bakım Kalitesinin Değerlendirilmesi Ölçeği' toplam puan, 'Psikososyal Bakım' ve 'Bilgilendirme' alt boyutlarında ortalama puanın altında puan aldıkları, 'Fiziksel Bakım' alt boyutunda ise ortalamanın üzerinde puan aldıkları belirlendi. Bu sonuçlar doğrultusunda hemşirelerin yatıştan itibaren çocuklara servis, hastalığ 1 ve tedavisi ile ilgili bilgilendirme yapmaları, çocukların hastanede eğlenceli vakit geçirmeleri için etkinlikler düzenlemeleri ve fiziksel bakım dışında da çocuklarla zaman geçirerek çocukların gereksinimlerini bütüncül değerlendirmeleri önerilebilir.

\section{Araştırmanın Sınırlılıkları}

Çalışmanın, Türkiye'nin Trakya Bölgesinde yer alan bir üniversite hastanesinde yapılması ve araştırmanın yürütüldüğü 'Çocuk Hastalıkları Servisinin' karma bir servis (nefroloji, endokrin, nöroloji, enfeksiyon, immünoloji anabilim dalı) olması çocukların sonuçlarının servislere göre karşılaştıılmasını sınırlamaktadır. $\mathrm{Bu}$ nedenle araştırma sonuçları çalışmanın yürütüldügü hastanede yatarak tedavi alan çocuklara genellenebilir.

\section{Teșekkür}

Çalışmaya katkı sağlayan ve değerli zamanlarını ayıran tüm ebeveynlere ve çocuklara katkılarından dolayı teşekkür ederiz.

\section{Araştırmanın Etik Yönü/ Ethics Committee Approval: Araştırma için Trakya Üniversitesi Tıp Fakültesi Dekanlığı, Bilimsel Araştırmalar Etik Kurulundan (TÜTF-BAEK 2019/76) ve Trakya Üniversitesi Sağlık Araştırma ve Uygulama Merkezi, Çocuk Sağlığı ve Hastalıkları Bilim Dalından gerekli yazılı izinler alındı. Araştırmaya katılan çocuklara ve ebeveynlere araştırmanın amacı açıklandı. Ebeveynlerden sözel ve yazılı onamları alınırken, çocuklarda sözel onamları alındı.}

Hakem/Peer-review: Dış hakem değerlendirmesi.

Yazar Katkısi/Author Contributions: Fikir/kavram: RS; Tasarım: RS, MAK; Danışmanlık: MAK; Veri Toplama: RS, İÇ, ENK; Veri İşleme: RS, İÇ, ENK; Analiz ve/veya Yorum: RS; Kaynak tarama; RS; Makalenin Yazımı: RS; Eleştirel inceleme: MAK.

Çıkar çatışması/Conflict of interest: Yazarlar arasında herhangi bir çıkar çatışması yoktur. Yazarların 
araștırmada herhangi bir firma ile çıkar ilișkisi de bulunmamaktadır.

Finansal Destek/Financial Disclosure: Herhangi bir finansal destek alınmamıştır.

\section{Çalışma Literatüre Ne Kattı?}

- Çocukların hemşirelerden aldıkları fiziksel bakım alt boyut puan ortalamaları, psikososyal bakım ve bilgilendirme alt boyut puan ortalamalarına göre daha yüksek düzeydedir.

- Hastane deneyimi ve kronik bir hastalığa sahip olan çocuklar, hemşirelik bakım kalitesini daha iyi değerlendirmektedir.

- Hastanede kalış süresi ve hastaneye yatış süresi arttan çocuklar, hemşirelik bakım kalitesini daha iyi değerlendirmektedir.

\section{Kaynaklar}

Açıkgöz A, Ezen M, Söngüt S, Ulukuş A, Emir B. (2019). Çocuğu hastanede yatan annelerde anksiyete ve depresif belirtilerin değerlendirilmesi. Acıbadem Üniversitesi Sağlık Bilimleri Dergisi, 10(3), 373-382.

Avan H. (2020). Hastane öncesi bakımda çocukla terapötik iletişim ve oyun. Hastane Öncesi Dergisi, 5(2), 109-118

Başbakkal Z, Sönmez S, Celasin NŞ, Esenay F. (2010). 3-6 yaş grubu çocuğun akut bir hastalık nedeniyle hastaneye yatışa karşı davranışsal tepkilerinin belirlenmesi. Uluslararası İnsan Bilimleri Dergisi, 7(1), 456-468.

Şen Beytut D, Bolışık B, Solak U, Seyfioğlu U. (2009). Çocuklarda hastaneye yatma etkilerinin projektif yöntem olan resim çizme yoluyla incelenmesi. Maltepe Üniversitesi Hemşirelik Bilim ve Sanatı Dergisi, 2(3), 36-44.

Bolat EY. (2018). Süreğen hastalığı olan çocuklar ve hastane okulları. Milli Eğitim Dergisi, 47(218), 163 186.

Boztepe H, Cinar S, Ay A. (2017). School-age children's perception of the hospital experience. Journal of Child Health Care, 21(2), 162-170.

Burns-Nader S. (2017). Examining children's healthcare experiences through drawings. Early Child Development and Care, 187(11), 1809-1818.

Comparcini D, Simonetti V, Tomietto M, Leino- Kilpi H, Pelander T, Cicolini G. (2018). Children's perceptions about the quality of pediatric nursing care: A large multicenter cross- sectional study. Journal of Nursing Scholarship, 50(3), 287-295.

Çakirer Çalbayram N, Altundağ S, Aydin B. (2018). Investigating children's perception of nurses through their drawings. Clinical Nursing Research, 27(8), 984-1001.

Gerçeker G, Ayar D, Özdemir Z, Bektaş M. (2018). Çocuk anksiyete skalası-durumluluk ve çocuk Korku ölçeğinin Türk diline kazandırılması. Dokuz Eylül
Üniversitesi Hemşirelik Fakültesi Elektronik Dergisi, 11(1), 9-13.

Gönener D. (2009). Okul yaş grubu çocukların hastane ve hastalığı ile ilgili bilgilendirme durumlarının endişe kaynakları ile etkileşimi. Gaziantep Medical Journal, 15(1), 41-48.

Gündüz S, Yüksel S, Aydeniz GE, Aydoğan RN, Türksoy H, Dikme İB ve ark. (2016). Çocuklarda hastane korkusunu etkileyen faktörler. Çocuk Sağlığı ve Hastalıkları Dergisi, 59, 161-168.

Harder M, Söderbäck M, Ranheim A. (2018). Health care professionals' perspective on children's participation in health care situations: encounters in mutuality and alienation. International Journal of Qualitative Studies on Health And Well-Being, 13(1), 1555421.

İnal Emiroğlu FN, Akay AP. (2008). Kronik hastalıklar, hastaneye yatış ve çocuk. Dokuz Eylül Üniversitesi Tıp Fakültesi Dergisi, 22(2), 99-105.

İnal S, Akgün M. (2003). Hastanede yatan çocukta terapötik iletişim. Anadolu Hemşirelik ve Sağllk Bilimleri Dergisi, 6(2), 67-76.

Loureiro F, Figueiredo MH, Charepe Z. (2019). Nursing care satisfaction from school- aged children's perspective: An integrative review. International Journal of Nursing Practice, 25(6), e12764.

Kapkin G, Manav G, Muslu GK. (2020). Effect of therapeutic play methods on hospitalized children in Turkey: A Systematic Review. Erciyes Medical Journal, 42(2), 127-142.

Melnyk BM. (2000). Intervention studies involving parents of hospitalized young children: an analysis of the past and future recommendations. Journal of Pediatric Nursing, 15(1), 4-13.

Noreña Peña AL, Cibanal Juan L. (2011). The experience of hospitalized children regarding their interactions with nursing professionals. Revista Latino-Americana de Enfermagem, 19(6), 1429-1436.

Öztürk ÖŞ, Topan A. (2018). Investigation of the fear of 7-18-year-old hospitalized children for illness and hospital. Journal of Religion and Health, 58(3), 10111023.

Pelander T, Leino-Kilpi H. (2004). Quality in pediatric nursing care: Children's expectations. Issues in Comprehensive Pediatric Nursing, 27(3), 139-151.

Pelander T, Leino-Kilpi H, Katajisto J. (2007). Quality of pediatric nursing care in Finland: Children's perspective. Journal of Nursing Care Quality, 22(2), 185-194.

Ryan-Wenger NA, Gardner W. (2012). Hospitalized children's perspectives on the quality and equity of their nursing care. Journal of Nursing Care Quality, 27(1), 35-42.

Silva RDMD, Austregésilo SC, Ithamar L, Lima LSD. (2017). Therapeutic play to prepare children for invasive procedures: a systematic review. Jornal de Pediatria, 93(1), 6-16.

Şener DK, Karaca A. (2017). Mutual expectations of mothers of hospitalized children and pediatric nurses 
who provided care: qualitative study. Journal of Pediatric Nursing, 34, e22-e28.

Taşdemir Akkavak D, Sarıkaya Karabudak S. (2019). Hastanede yatan okul çağı çocukların hemşireyi ve hastaneyi algılama durumlarının incelenmesi. Dokuz Eylül Üniversitesi Hemşirelik Fakültesi Elektronik Dergisi, 12(1), 46-56

Teksoz E, Bilgin I, Madzwamuse SE, Ocakci AF. (2017). The impact of a creative play intervention on satisfaction with nursing care: A mixed- methods study. Journal for Specialists in Pediatric Nursing, 22(1), e12169.

Temel ZF, Kanat K, Kaynak Ekici KB, Canberi F. (2018). Hastaneye yatma deneyimi olan ve olmayan 5-6 yaş çocuklarının doktor, hemşire ve hastane algılarının incelenmesi. Turkish Journal of Social Research, 22, 251-278.

Vessey JA. (2003). Children's psychological responses to hospitalization. Annual Review of Nursing Research, 21(1), 173-201.

Wilson ME, Megel ME, Enenbach L, Carlson KL. (2010). The voices of children: stories about hospitalization. Journal of Pediatric Health Care, 24(2), 95-102.

Yagil D, Luria G, Admi H, Moshe- Eilon Y, Linn S. (2010). Parents, spouses, and children of hospitalized patients: evaluation of nursing care. Journal of Advanced Nursing, 66(8), 1793-1801.

Yati M, Wahyuni S, Islaeli I. (2017). The effect of storytelling in a play therapy on anxiety level in preschool children during hospitalization in the general hospital of buton. Public Health of Indonesia, 3(3), 2477-1570.

Yayan EH, Zengin M. (2018). Çocuk kliniklerinde terapötik oyun. Gümüşhane Üniversitesi Sağlık Bilimleri Dergisi, 7(1), 226-233.

Yılmaz M. (2018). Çocukların gözü ile bakım kalitesinin değerlendirilmesi: Bir ölçek geliştirme çalışması. 5 . Ulusal 1. Uluslararası Hemşirelikte Güncel Yaklaşımlar Kongresi; 15-17 Kasım 2018; Sakarya. 